\title{
THE POSSIBILITY OF COPROCESSING MUNICIPAL SOLID WASTE - MSW IN CLINKER KILNS TO CEMENT PRODUCTION
}

\author{
J. A. Meystre, \\ and R. J. Silva \\ Universidade Federal de Itajubá \\ Instituto de Engenharia Mecânica - IEM \\ Avenida BPS, 1303, Bairro Pinheirinho \\ Itajubá, Minas Gerais, Brasi \\ CEP 37500-000 \\ josue.meystre@unifei.edu.br \\ rogeriojs@unifei.edu.b
}

Received: October 25, 2013 Revised: November 21, 2013 Accepted: December 30, 2013

\section{ABSTRACT}

The objective of this paper is to present an analysis of coprocessing in a cement production plant using Municipal Solid Waste - MSW as a secondary fuel and show the main advantages that burn into a incineration plant. The manufacture of Portland cement is a process that requires a large consumption of thermal and electrical energy and front of the immense worldwide energetic demand has increased its value every day. The typical operating cost involving this energy achieves $40 \%$ of the final product and due to increasing world consumption justifies the efforts to reduce the costs associated with its production. The use of high efficiency equipment coupled with the replacement of fossil fuels and conventional raw material for alternative products has given good results. The method of disposal of MSW in landfills in large urban centers is being used less and less. The creation of environmental laws increasingly severe shortages of allied areas not disturbed and the high cost of construction and operation of landfills hinders its viability. Moreover, there is a problem related to the emissions of gaseous and liquid effluents that help raise the cost for its control and treatment. The MSW, when recovered and separated, can become recyclable products and as energy sources. After separation of the usable material (organic matter and recyclable), remaining MSW materials with sufficient calorific value can be used in kilns to produce clinker. Moreover, the ash resulting from combustion may be incorporated in the clinker decreasing the initial amount of raw material. The use of MSW as alternative fuel has shown to be feasible in the clinker kiln, but their use is still limited by their availability, since their segregation is rarely practiced. The substitution of alternative inputs introduce restrictions to the process which must be safely handled in order to ensure the minimum quality and productivity of cement production plants. The use of MSW must have a thorough characterization of your composition, because of directly influences in the final product.

Keywords: Municipal Solid Waste, Coprocessing, Incineration, Clinker Kiln

\section{NOMENCLATURE}

APC Air Pollution Control

CDM Clean Development Mechanism

GHG Greenhouse Gas

MSW Municipal Solid Waste

MSWI Municipal Solid Waste Incineration

RDF Refuse Derived Fuel

\section{INTRODUCTION}

The system of production and consumption adopted by the world's population during the last decades not considered the necessity of efficient technologies to perform the final processing and disposal of their waste. Now, a large amount of waste generation is causing serious problems for the society.

Poor waste management is a challenge in developing countries and in countries in transition. In
Brazil, while the average geometric rate of annual population growth was only $1.17 \%$ in 2010 (IBGE, 2012) research "Overview of solid waste in Brazil 2010” (Abrelpe, 2010) report that in the same period, the volume of municipal waste generated by the population grew by $6.8 \%$. According to "National research of basic sanitation - 2008” (IBGE, 2010), the residential and commercial solid waste collected in urban areas in $50.8 \%$ of Brazilian municipalities are disposed in open dumps.

Municipal Solid Waste - MSW normally are disposed in open dumps and sanitary landfill or are recycled, composted, incinerated, pyrolysed or even treated for energy recovery in specific plants. Most of these methods reduce the problem of MSW, but they create other environmental problems (Ali and Chang, 1994; Tchobanoglous et al., 1993).

The main negative environmental impacts caused by the irregular disposal of MSW are the potential risk of groundwater, surface water and soil 
contamination by leachate, the proliferation of vector-borne diseases transmission and air pollution that increasing Greenhouse Gas - GHG emissions. This situation shows the gravity as the form to disposal urban waste and point to the importance of establishing mechanisms that include its management.

Sanitary landfills have been used as the most economical and environmentally friendly solution to the disposal of MSW. However, actually the method of disposal of MSW in landfills in large urban centers is being used less and less.

The creation of environmental regulations ever more severe combined with unavailability sites and high cost for acquiring areas, construction, operation and monitoring of sanitary landfills hinders its viability and therefore alternatives solutions must be found.

Waste reduction by recycling or any other treatment is also an important part of any integrated solid waste-management system. The Council of the European Union published Directive 1999/31/EC on the landfill of waste where, European landfills are not authorized to receive MSW to which no pretreatments have been applied (CEU, 1999).

Thermal treatment is one of valid solutions for reducing the amount of urban waste to be landfilled and, in most cases, for recovering the energy content of the waste. In the 1970's begins a significant use of incineration for MSW treatment. However, due to lack of knowledge relating to emissions problems and poor incinerator design, these early MSW incinerators developed a bad environmental reputation (Shaub and Tsang, 1983; Stieglitz and Vogg, 1987).

The significant advances in the technologies separation of materials from MSW and incineration plants design recovery the way of heat and, power production has again gained favor in the last decades (Addlink and Olie, 1995; Kilgroe, 1996; Andersson et al., 1998; McKay, 2002),

However due to the fact that the operational costs as well as the transport cost are high, the use of incineration as a waste management method will be usually adopted in large urban areas (Sikalidis et al., 2002). A paper by members of a European working group called "Phoenix" deals with the practical problems, related in his research that the thermal treatment of MSW when incinerated produces residues that are considered as ultimate waste and, after a solidification and stabilization process, must be stored in landfill (Sabbas et al., 2003).

The coprocessing of MSW in kilns clinker to produce Portland cement can supply the deficiency of the usual incineration process. The coprocessing of MSW together into kilns Clinker production can be considered a viable and environmentally friendly because all processed waste is mineralized in ovens at high temperatures serving as fuel and as raw material. This measure, besides consolidating thoughts of energy efficiency, development and reuse of waste, also qualifies as a Clean Development Mechanism CDM to reduce GHG and consequent achievement of quotas for carbon credits.

This study reports what has been done in the world scenario for the integration of the MSW incineration process as the process of manufacture of cement and discusses the synergistic combination of components to obtain a higher productive efficiency.

\section{MUNICIPAL SOLID WASTE}

There are several definitions for MSW in various literary works (Wagner, 1994; Eduljee and Arthur, 1996; Tchobanoglous et al., 1993). For the Council of The European Communities, directive 75/442/EEC on waste defines waste as "any substance or object which the holder disposes of or it required disposing of pursuant to the provisions of national law in force" (CEC, 1975). Altogether, those who have the source residential, commercial, industrial or public service activities and are not classified as a hazardous waste, are often called the Municipal Solid Waste - MSW.

The quality and quantity of MSW generated by a given population have the characteristics variation as condition socio economic and cultural, climate, geographic location, urban infrastructure and the preponderance of local economic activities (Christopoulos, 2005).

The calorific value of MSW can be obtained through the analysis of their elemental composition that varies according to its characteristics. Typical values reported in the literature is respectively 9,235 $\mathrm{kJ} / \mathrm{kg}, 8,400 \mathrm{~kJ} / \mathrm{kg}$ 10,110 kJ/kg 13,591 kJ/kg (Haley, 1985; Morcos, 1989; Consonni et al, 2005 and Choy et al., 2004).

Municipal Solid Waste shall be incinerated only if there is no financially and ecologically better way of waste avoidance and recycling (GTZ and Holcim, 2006). The waste management hierarchy is shown in Fig. 1.

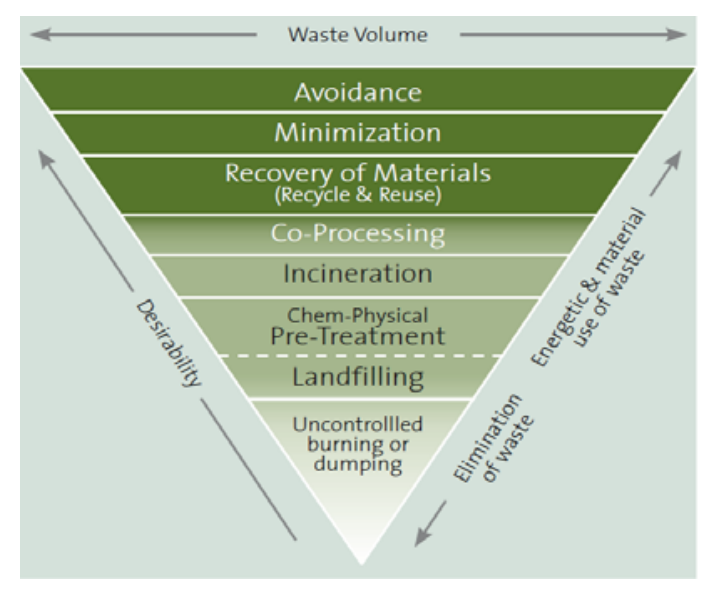

Figure 1. Waste Management Hierarchy (GTZ and Holcim, 2006). 


\section{AN INTRODUCTION OF THERMAL TREATMENT}

Combustion and other forms of thermal treatment have, over the years, been adopted as proven and the best available techniques to dispose of hazardous waste, municipal solid waste and medical waste (Lee et al., 2000; Dempsey and Oppelt, 1993).

The thermal treatment by combustion is a combination of pyrolysis and oxidation. Pyrolysis is a chemical change resulting from heat alone and involves the breaking of stable chemical bonds, often resulting in molecular rearrangement. Oxidation is the gross reaction of an organic species with oxygen and requires relatively low activation energies (Niessen, 1995). For efficient combustion, oxidation should be the dominant process, with pyrolysis occurring either incidentally to the oxidation or to put a material into a better physical form for oxidation. To combust solid wastes effectively, pyrolysis must be efficient and complete before oxidation of the molecular chemical by-products can occur.

The thermal treatment by combustion is a combination of pyrolysis and oxidation. Pyrolysis is a chemical change resulting from heat alone and involves the breaking of stable chemical bonds, often resulting in molecular rearrangement. Oxidation is the gross reaction of an organic species with oxygen and requires relatively low activation energies (Niessen, 1995). For efficient combustion, oxidation should be the dominant process, with pyrolysis occurring either incidentally to the oxidation or to put a material into a better physical form for oxidation. To combust solid wastes effectively, pyrolysis must be efficient and complete before oxidation of the molecular chemical by-products can occur.

Combustion temperature and residence time needed for totality destruction of MSW cannot be readily calculated and are often determined empirically. To achieve a complete thermal destruction, sufficient temperature, oxygen supply, residence time and mixing conditions are needed (Brunner 1993; Dempsey and Oppelt, 1993).

Both dedicated incinerators and cement kilns can achieve a complete thermal destruction of municipal solid wastes and fulfill the combustion requirements with respect to safe and sound destruction of hazardous wastes (Chadbourne, 1997). However, cement kilns usually have higher temperatures and longer residence times than waste incinerators (Brunner 1993; Dempsey and Oppelt 1993; Niessen 1995).

\section{MUNICIPAL SOLID WASTE INCINERATION}

Many highly-developed countries keep searching for waste treatment methods that would be friendly to the environment and helpful in recovering energy from waste. Municipal Solid Waste Incineration - MSWI is one of these methods and is utilized until now.

Most countries of Europe besides the USA, Japan and Korea have been operating incinerator units (EC-DGE, 2003; Shin and Chang, 1999). The benefits of modern incineration plants are: the significantly reduced of $85-90 \%$ by initial volume of the MSW; the location of incinerator site reduces transportation costs; the energy sales from heat recovery offset the operating (Cheung et al., 2006).

Meanwhile MSWI not only produces significant pollutant flue gases, but also gives rise to considerable amount of solid residues where are generated at several points in the process and are routinely classified into three categories: bottom ash, fly ash and combination of both (Chandler et al., 1997). Usually solids retained on furnace grates following combustion and solids passing through the grates are referred to as bottom ash. In the other hand entrained particulates that are trapped and residues generated by acid gas scrubbers and subsequently removed by filters or electrostatic precipitators normally referred to as Air Pollution Control - APC residue or as a fly ash (Wiles, 1996).

With improvements in APC systems, modern MSWI plants emit practically no pollutants into the atmosphere and basically the hazardous fractions in MSW are concentrated in the solid residues ( $\mathrm{Li}$ et al., 2004). The presence of residual amounts of hazardous organics in high concentrations of heavy metals and soluble salts are caused by transfer of volatile composts in the combustion chamber and subsequent precipitation in the APC units (Shi and Kan, 2009).

In many literature sources is reported that the physical and chemical characteristics of solid residues from MSWI depend on many factors: such as the composition of feed MSW, the type of incinerator, the APC devices, the operating conditions and so on (Chandler et al., 1997). Table 1 and Tab. 2 (adapted from Shi and Kan, 2009; Li et al., 2004; Seemann, 2007; Wiles, 1996) shows ash composition and heavy metals concentration founded in solid residues from MSWI.

Table 1. Ash composition in solid residues from MSWI.

\begin{tabular}{|c|c|c|c|}
\hline \multicolumn{4}{|c|}{ Component (wt\% by weight) } \\
\hline $\mathrm{SiO}_{2}$ & $\mathrm{Al}_{2} \mathrm{O}_{3}$ & $\mathrm{Fe}_{2} \mathrm{O}_{3}$ & $\mathrm{CaO}$ \\
\hline $8.6-40.0$ & $1.7-8.4$ & $2.6-5.8$ & $13.9-3.5$ \\
\hline $\mathrm{MgO}$ & $\mathrm{Na}_{2} \mathrm{O}$ & $\mathrm{K}_{2} \mathrm{O}$ & $\mathrm{TiO}_{2}$ \\
\hline $3.1-6.4$ & $1.0-14$ & $1.4-8.8$ & $0.6-1.2$ \\
\hline $\mathrm{P}_{2} \mathrm{O}_{5}$ & $\mathrm{MnO}$ & $\mathrm{SO}_{3}$ & $\mathrm{Cl}$ \\
\hline $1.1-8.0$ & $0.12-0.17$ & $2.5-22.5$ & $0.4-12.8$ \\
\hline
\end{tabular}


Table 2. Heavy metals concentration in solid residues from MSWI.

\begin{tabular}{|c|c|c|c|}
\hline \multicolumn{4}{|c|}{ Heavy metal (mg/kg) } \\
\hline $\mathrm{Cd}$ & $\mathrm{Zn}$ & $\mathrm{Cu}$ & $\mathrm{Ni}$ \\
\hline $23-1596$ & $2809-7118$ & $804-2641$ & $74-718$ \\
\hline $\mathrm{Cr}$ & $\mathrm{Pb}$ & $\mathrm{Hg}$ & $\mathrm{As}$ \\
\hline $189-1657$ & $647-6793$ & $0.004-0.435$ & $29-295$ \\
\hline
\end{tabular}

\section{COPROCESSING OF MSW IN CEMENT KILN}

The manufacture of Portland cement is a process that requires a large consumption of thermal and electrical energy. The immense worldwide energetic demand combined with fuel deficit, increasing fuel prices every day and forces the cement industry to search for technologies based on waste-derived and alternative fuels (Mokrzycki and Uliasz-Bochenczyk, 2003).

Various methods of treating MSWI ashes such as melting, solidification, stabilization, acid extraction, vitrification, and sintering have been used to final disposition of MSWI solid residues.

In the most recent years, some researchers have studied the possibility of burn MSW in cement kilns. These researchers have investigated the possibility of coprocessing MSW as raw materials and energy source for the production of Portland cement clinker.

Traditionally, the primary fuel has been coal, but a wide range of other fuels is also used, including petroleum coke, natural gas and oil. Coprocessing refers to the use of waste materials, such as cement production. The coprocessing of selected waste materials in the cement industry is a proved alternative and possible solution for treatment of high caloric wastes. Coprocessing has the following characteristics during the production process: alkaline conditions and the intensive mixing favors the absorption of volatile components from the gas phase and the clinker reactions at $1450^{\circ} \mathrm{C}$ allow incorporation of ashes and in particular the chemical binding of metals to the clinker (Seemann, 2007).

A schematic diagram of a typical cement industry using alternative fuel and raw materials is illustrated in Fig. 2 (GTZ and Holcim, 2006).

The coprocessing of MSW in clinker kilns is conditioned to a pre-treatment that ensure the segregation of recyclable materials and organic fraction with high content of wet. The reject of this segregation is called Refuse Derived Fuel - RDF and thus can be used as secondary fuel in the kiln clinker production. Further, the ashes produced by combustion of RDF can be incorporated in the clinker as inert thus decreasing the required quantity of raw material (Sikalidis et al. 2002).

In Europe, about 115,000 tons per year of RDF were supplied of urban waste was coprocessing in cement kilns in 1997 (RDC/KEMA, 1999), and in 2003 this value has already surpassed the 300,000 tons per year (EC-DGE, 2003).

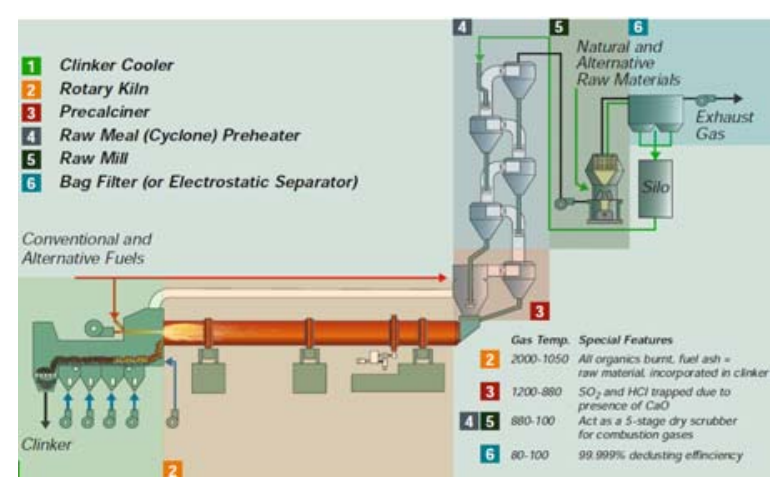

Figure 2. Schematic diagram of a cement industry using alternative fuel and raw materials (GTZ and Holcim, 2006).

\section{CONCLUSIONS}

The high calorific fraction of municipal solid waste can be used as secondary fuel in cement industry according to its physical composition. However, to obtain the high calorific fraction of municipal solid waste a pre treatment of the waste is absolutely required.

The conditions in rotary kilns, such as high temperature, the high speed of the gas stream and the long particle-storage period, guarantee that the use of alternative fuels is ecologically safe.

Despite the possibility of using municipal solid waste as recovery of thermal energy in the two systems analyzed, incineration and coprocessing in cement clinker kilns, concerning the chemical properties of the material there are still some open points. Ash composition and heavy metals concentration generated after incineration of solid residues from urban waste can modify the final quality of the cement.

The main advantages are found the total destruction of MSW with the final conversion to a product with economic value, the replacement of fossil fuels with alternative fuels and increasing the economic viability of the cement plant. Moreover, MSW can be used by the high energy demanding cement industry saving the natural coal and fossil fuel resources.

\section{ACKNOWLEDGEMENTS}

The paper authors acknowledge the Fundação de Amparo à Pesquisa do Estado de Minas Gerais FAPEMIG, CNPq and CAPES for financial support received.

\section{REFERENCES}

ABRELPE - Associação Brasileira de Empresas de Limpeza Pública e Resíduos Especiais, 2010, Overview of Solid Waste in Brazil - 2010, São Paulo, Brasil. 
Addink, R., and Olie, K., 1995, Mechanisms of Formation and Destruction of Polychlorinated Dibenzo-p-Dioxins and Dibenzofurans in Heterogeneous Systems, Environmental Science and Technology, Vol. 29, pp. 1425-1435.

Ali, M. T., and Chang, W. F., 1994, Strength Properties of Cement-Stabilized Municipal Solid Waste Incinerator Ash Masonry Bricks, ACI Materials Journal, Vol. 91, pp. 256 - 263.

Andersson, P., Rappe, C., Maaskant, O., Unsworth, J. F., and Marklund, S., 1998, Low Temperature Catalytic Destruction of PCDD-F in Flue Gas from Waste Incineration, Organohalogen Compounds, Vol. 36, pp. 109-112.

Brunner, C. R., 1993, Hazardous Waste Incineration, McGraw-Hill, Inc. New York.

CEC - The Council Of The European Communities, 1975, Council Directive 75/442/EEC of 15 July 1975 on Waste, Official Journal of the European Communities, No. L 194, pp. 39.

CEU - The Council of European Union, 1999, Council Directive 1999/31/EC of 26 April 1999 on the Landfill of Waste, Official Journal of the European Communities, No. L 182, pp. 1-19.

Chandler, A. J., Eighmy, T. T., Hjelmar, J. H., Kosson, D. S., Sawell, S. E., Van der Sloet, H. A., and Vehlow, J., 1997, Municipal Solid Waste Incinerator Residues, Studies in Environmental Science, Elsevier Science, Vol. 67.

Chadbourne, J. F., 1997, Cement Kilns Standard Handbook of Hazardous Waste Treatment and Disposal, McGraw-Hill, Inc. New York.

Cheung W. H., Choy K. K. H., Hui D. C. W., Porter J. F., and Mckay, G., 2006, Use of Municipal Solid Waste for Integrated Cement Production, Asia Pacific Journal of Chemical Engineering, Vol. 14, pp. 193-202.

Choy, K. K. H., Ko, D. C. K., Cheung, W. H., Fung, J. S. C., Hui, D. C. W., Porter, J. F., and McKay, G., 2004, Municipal Solid Waste Utilization for Integrated Cement Processing with Waste Minimization. A Pilot Scale Proposal, Process Safety and Environmental Protection, Vol. 82, pp. 200-207.

Christopoulos, P. G., 2005, Waste Treatment in Greece After the Passage of EU Landfill Directive. Landfill Bioreactor Cell Treatment as Sustainable Solution, Doctoral Thesis, Lund University, Lund, Sweden.

Consonni, S., Giugliano, M., and Grosso, M., 2005, Alternative Strategies for Energy Recovery from Municipal Solid Waste. Part A: Mass and Energy Balances, Waste Management, Vol. 25, pp. 123-135.

Dempsey, C. R., and Oppelt, E. T., 1993, Incineration of Hazardous Waste: A Critical Review Update, Air \& Waste, Vol. 43, pp. 25-73.

EC-DGE - European Commission - Directorate General Environment, 2003, Refuse Derived Fuel, Current Practice and Perspectives (B4-
3040/2000/306517/MAR/E3) - Final Report, WRc Ref: CO 5087-4, pp. 219.

Eduljee, G. H., and Arthur, D. A., 1996, Solid Waste Management, In: Pollution: Causes, Effects, and Control, The Royal Society of Chemistry, Cambridge, UK, pp. 340-366.

GTZ - Deutsche Gesellschaft für Technische Zusammenarbeit and Holcim Group Support Ltd, 2006, Guidelines on Co-processing Waste Materials in Cement Production, Institute for Ecopreneurship (IEC) of the University of Applied Sciences, Northwestern Switzerland.

IBGE - Instituto Brasileiro de Geografia e Estatística, 2010, National Research of Basic Sanitation - 2008, Rio de Janeiro, Brasil.

IBGE - Instituto Brasileiro de Geografia e Estatística, 2012, Demographic Census 2010, Rio de Janeiro, Brasil.

Haley, C. A. C., 1985, The Use of Refuse Derived Fuel in Cement Manufacture, Ciments, Bétons, Plâtes, Chaux, No. 754, pp. 155-158.

Kilgroe, J. D., 1996, Control of Dioxin, Furan and Mercury Emissions from Municipal Waste Combustors, J. Hazard. Mater, Vol. 47, pp. 163-194.

Lee, C. C., Huffman, G. L., and Mao, Y. L., 2000, Regulatory Framework for the Thermal Treatment of Various Waste Streams, Journal of Hazardous Materials, Vol. 76, pp. 13-22.

Li, M., Xiang, J., Hu, S., Sun, L., Su, S., Li, P., and Sun, X., 2004, Characterization of Solid Residues from Municipal Solid Waste Incinerator, Fuel, Vol. 83, pp. 1397-1405

McKay, G., 2002, Dioxin Characterisation, Formation and Minimization During Municipal Solid Waste (MSW) Incineration: Review, Chem. Eng. J., Vol. 86, pp. 343-368.

Mokrzycki, E., and Uliasz-Bochenczyk, A., 2003, Alternative Fuels for the Cement Industry, Applied Energy, Vol. 74, pp. 95-100.

Morcos, V. H., 1989, Energy Recovery from Municipal Solid Waste Incineration - A Review, Heat Recovery Systems \& CHP, Vol. 9, No. 2, pp. 115-126.

Niessen, W. R., 1995, Combustion and Incineration Processes, Marcel Dekker, Inc., New York.

RDC/KEMA, 1999, Comparative Study on the Environmental Performances of Co-Incineration and Specialized Incineration - Final Report, Study Performed for the European Commission, DG XI, Ref. No.: B4-3040/98/ 000109/MAR/E1.

Sabbas, T., Polettini, A., Pomi, R., Astrup, T., Hjelmar, O., Mostbauer, P., Cappai, G., Magel, G., Salhofer, S., Speiser, C., Heuss-Assbichler, S., Klein, R., and Lechner, P., 2003, Management of Municipal Solid Waste Incineration Residues, Waste Manage, Vol. 23, pp. 61-88.

Seemann, A., 2007, Co-incineration of Municipal Solid Waste in Cement Industry Proceedings, in: International Conference on 
Sustainable Solid Waste Management, Chennai, India, pp. 348-355

Shaub, W. M., and Tsang, W., 1983, Dioxin Formation in Incinerators, Environmental Science and Technology, Vol. 17, pp. 721-730.

Shi, H. -s., and Kan, L. -l., 2009, Characteristics of Municipal Solid Wastes Incineration (MSWI) Fly Ash-Cement Matrices and Effect of Mineral Admixtures on Composite System, Construction and Building Materials, Vol. 23, pp. 2160-2166.

Shin, K. J., and Chang, Y. S., 1999, Characterization of Polychlorinated Dibenzo-PDioxins, Dibenzofurans, Biphenyls, and Heavy Metals in Fly Ash Produced from Korean Municipal Solid Waste Incinerators, Chemosphere, Vol. 38, pp. 2655-2666.

Sikalidis, C. A., Zabaniotou A. A., and Famellos S. P., 2002, Utilization of Municipal Solid Wastes for Mortar Production, Resources, Conservation and Recycling, No. 36, pp. 155-167.

Stieglitz, L., and Vogg, H., 1987, On Formation Conditions of PCDD - PCDF in Fly Ash from Municipal Waste Incinerators, Chemosphere, Vol.16, pp. 1917-1922.

Tchobanoglous, G., Theisen, H., and Vigil, S., 1993, Integrated Solid Waste Management: Engineering Principles and Management Issues. McGraw-Hill, New York.

Wagner, T., 1994, In Our Backyard: A Guide to Understanding Pollution and Its Effects, John Wiley \& Sons, New York.

Wiles, C. C., 1996, Municipal Solid Waste Combustion Ash: State-of-the-knowledge, Journal of Hazardous Materials, Vol. 47, pp 325-344. 